\title{
Zimní sporty ve Speciálních olympiádách
}

\section{Winter sports within Special Olympics}

\author{
Hana Válková \\ Fakulta tělesné kultury, Univerzita Palackého, Olomouc, \\ Česká republika
}

\section{Abstrakt:}

Pohybové aktivity a sporty v zimním prostredí jsou součástí spektra možných aktivit osob s postižením. Teoretická studie se koncentruje na popis zimnich sportů ve schématu: a) rozdily v pojetí Inas-FID a Speciálnich olympiád; b) prehled světových her $S O$ a národních her $S O$; c) výčet disciplín zimních sportů na světových hrách $S O$ a v národnich hrách SO; d) specifická pravidla volby disciplín dle schopností sportovců; e) řě̌ení pravidla "maximálního úsili",; f) možnosti zapojení do Speciálních olympiád a tudiž zimnich sportü.

\section{Abstract:}

Physical activities and sports in winter outdoor environment are the part of spectrum of possible activities of persons with intellectual disability. Theoretical study is focused on description of winter sports related to domains: a) different approaches in Inas-FID and Special Olympics; b) survey of World Winter Games and national games of SO; c) check-list of winter sports included in World Special Olympic Games and in Czech National program; d) specific regulations of sports selection according sportsman abilities; e) ,maximal effort" regulation; f) possibilities of participation in Special Olympics, and winter sports.

Klíčová slova: mentální postižení, Inas-FID, Speciální olympiády, lyžováni běžecké, lyžováni sjezdové. 
Key words: intellectual disability, Inas-FID, Special Olympics, crosscountry skiing, alpine skiing.

Práce vznikla v rámci projektu ESF reg. č. CZ 1.07/1.2.00/14.0021 „Speciálně poradenské centrum aplikovaných pohybových aktivit".

\section{ÚVOD}

Pro určitá geografická území je stř́dání typických čtyř ročních období príznačné. Obecně podnebí a aktuální počasí ovlivňuje životní styl obyvatel, jejich každodenní činnosti i kulturní a sportovní orientaci. Dokonce i charakteristické dovednosti, jinými slovy lidská motorika, jsou determinovány faktory geografickými, kulturními, historickými, ekonomickými. Tato fakta se intenzivně týkají i rozvoje zimních sportů. Uchopení činností v zimní prírodě, participace i v zimních soutěžních sportech se nám může zdát běžné a bezproblémové, nemusí to být tak jednoduché pro osoby s určitým typem ,jinakosti“. Konkrétně se budeme zabývat zimními sporty osob $\mathrm{s}$ mentálním postižením (MP), konkrétně $\mathrm{v}$ rámci Speciálních olympiád. Při pátrání po adekvátní literatuře včetně internetových zdrojů nalézáme informace málo frekventované a poměrně chudé. Některé prezentujeme $\mathrm{v}$ chronologickém pořadí vydání. Začneme klasiky aplikovaných pohybových aktivit (APA) a pohybových aktivit osob s MP (Sherrill, 2003; Winnick, 1990). Nalezneme pouze výčet sportů $\mathrm{v}$ rámci Inas (International Federation for sport of mentally handicapped, později - of intellectual disability) nebo v rámci SOI (SpecialOlympics International). Dvourádkovou zmínku o zimních sportech zařadil Shephard k informacím o typech sportovní klasifikace ve sportu osob s tělesným postižením (Shephard, 1990, 58). Výzkumné práce, publikované v časopise Adapted Physical Activity Quarterly (APAQ) v letech 1993-2004, se netýkají prostředí zimních sportů (Porretta \& Sherrill, 2005). Ani v archívu statí APAQ od roku 2005 až do současnosti se téma zimních sportů nevyskytuje.

DePauw a Gavron $(2005,101,141)$ uvádějí přehled zimních sportů v kategoriálním pojetí (Paralympiády, Deaflympiády a Speciální olym- 
piády) a místa konání zimních her. Shodné údaje na jedné straně formátu A5 nalezneme i ve 25 stránkové prŕíručce (Ješina, 2007). Také další stručná prŕručka k tématu ,zimní sporty osob s MP“ prezentuje charakteristiku mentálního postižení dle WHO a obecné principy řešení pohybových aktivit (PA), tj. obecné didaktické zásady, metodické podněty, pojednání o důležitost pohybu obecně pro osobnostní a sociální rozvoj osob s MP. Dále zde nalezneme výčet sportů v rámci Českého svazu mentálně postižených sportovců (ČSMPS), který je ovšem zaměněn za výčet sportů ve Speciálních olympiádách (SO), (Ješina, Janečka \& all, 2008, 55-58). Rozsáhlejší text Ješiny a Kudláčka a kolektivu (2011) v kapitole 10 (str. 113-119) se zaměřuje na aplikované pohybové aktivity (APA) žáků s MP (autor Ješina). Znovu se opakuje charakteristika žáků s MP a obecné zásady, o zimních sportech není zmínka. Pohybovými aktivitami osob s postižením v kontextu volného času se zabývají Ješina a Hamř́k a kolektiv (2011). Kapitola 5.2 (str. 99-102) věnované volnočasovým aktivitám osob $\mathrm{s}$ MP (autor Ješina) v podstatě rozšiřuje text z roku 2008 (Ješina, Janečka \& all, 2008), novým doplňkem je srovnání sportovního pojetí v rámci Inas (ČSMPS) a SO a o uvedení výzkumu Válkové (2000) dokumentujícího význam, především sociální, programů SO. O zimních sportech není zmínka.

Opačný pól širokého spektra PA, soutěžní sport, popisují Janečka a kol. (2012). Sporty osob s MP jsou prezentovány v kapitole 4 (str. 101-107, autorka Válková). Nalezneme zde popis podmínek pro účast ve sportu od začátečníků po začlenění ve sportovním směru Inas-FID (ČSMPS) a SO (ČHSO), dále výčet sportů, tedy i zimních v obou sportovních směrech. V rámci SO je vysvětleno pojetí sjednoceného sportu ve floorhokeji (unified: www.specialolympics.org).

Ani kohezivní kniha s názvem „Sport osob s intelektovým postižením“ (Tilinger, Lejčarová a kol., 2012) nevěnuje pozornost zimním sportům, pouze jejich výčtu. Část orientovaná na Inas-FID (ČSMPS) detailně popisuje tento sportovní soutěžní směr, část týkající se SO je nepřesná, včetně výčtu zimních sportů.

$\mathrm{V}$ souhrnu dojdeme $\mathrm{k}$ názoru, že $\mathrm{v}$ dostupné literatuře bud' téma zimních sportů osob $\mathrm{s}$ mentálním postižením, z jakéhokoliv hlediska, 
bud' absentuje vůbec, nebo mnohoslibné tituly uvádějí obecné informace a maximálně výčet sportů. $O$ příčinách nám nepř́isluší spekulovat, v každém př́padě jsou i výzvou do další práce, protože zimní sporty konkrétně ve Speciálních olympiádách hrají významnou úlohu. Předložená stat', orientovaná na zimní sporty v rámci Speciálních olympiád, především pak na běžecké lyžování, může být jedním z prvních kroků.

\section{Podmínky pro zvládnutí soutěžního sportu v rámci Speciálních olympiád}

Účast na národních či světových zimních hrách Speciálních olympiád vyžaduje dlouhodobou př́ípravu, jako ve sportu obecně. Úspěšná realizace programů PA a sportu je založena na principu:

a) zvládnutí oboustranné komunikace (Válková, 2012, 57-60),

b) adaptování na zimní prostředí (chlad - oblečení, pocit skluzu při chůzi či pohybu obecně, překonání obav z nového prostředí, vstřebání pocitu přiměřené rychlosti),

c) vytvoření pozitivního postoje $\mathrm{k}$ PA a sportu v zimní př́rodě, posílení vnitřní motivace $\mathrm{k}$ účasti a k sebezdokonalování.

Samozřejmě že je nutné respektovat veškeré didaktické zásady, formulované už Komenským (přiměřenost, postup od jednoduššího ke složitějšímu, systematičnost, individualizace, atd.). Užití těchto zásad považujeme za součást komunikace se sportujícími s MP. Vzhledem $\mathrm{k}$ problémům $\mathrm{v}$ komunikaci podtrhujeme praktickou poučku: nevykládej - ukaž - a vyzvi k nápodobě (dělej to jako já, opakuj to po mně). V počátku je třeba dát prostor ke spontánnímu pohybu v zimním terénu (různá hloubka sněhu, různě kluzký terén), což se navodí např. hudbou na cestě před chalupou. Prvotní hry jsou s použitím NIČEHO, postupně se přidávají činnosti s míči, se sněhovými koulemi, s pomůckami pro klouzání. Před-lyžařská př́íprava na sněhu by měla být podpořena obdobnou „suchou přípravou“ v tělocvičně: cvičení pro rovnováhu a cvičení pro pocit skluzu. Pak nastupují cvičení s lyžemi na nohou bez holí, později s holemi. Různé typy průpravných cvičení na běžkách (,koloběžka“, 
různé typy úchopu holí pro zdůraznění práce paží apod.) v počátku nejsou úspěšné, protože sportovec si nespojí schéma s reálným pohybem. Ř́zené motorické učení nastupuje v momentě, kdy sportovec s MP už na běžkách $C H O D I ́$ a KLOUŽE SE a po pádu se umí zvednout, a to i na svahu.

\section{Zimní sporty v rámci Inas-FID (ČSMPS) a SO (ČHSO)}

Jedním ze směrů garantujících a rozvíjejících sportovní činnost osob s MP, který směřuje $\mathrm{k}$ vrcholovým soutěžím, je mezinárodní federace Inas - FID (International Sports Federation of para-athletes with intellectual disability). Sportovní filozofie je založena na principu „normality“. Tento princip vychází z téze, že všichni sportující podléhají jedné normě, srovnávají se s jednou normou a jsou hodnoceni dle jedné normy. Tj. - podléhají jednomu systému postupových kvalifikací, limitů, reflektují věkové kategorie daného sportu v souladu se sporty běžnými. Jasná kritéria jsou výhodou pro hodnocení postupu do vyšších soutěžení, ale sekundárně takto preferují sportovce s mírnějším mentálním postižením, avšak pod hranicí IQ 75 bodů.

V současné době je zpracován precizní, byt' komplikovaný, systém i proces získání licence intelektově postiženého sportovce pro účast v soutěžích Inas a IPC. Principy tohoto procesu uvádí Tilinger, Lejčarová a kol. (2012) a http://www.inas.org/technical/eligibility-and-classification/. Inas-FID (a tudíž ČSMPS) vzhledem k principu normality neumožňuje žádné modifikace sportů či jejich disciplín, takže v zimních sportech se soutěží pouze v disciplínách sjezdového a běžeckého lyžování relevantní běžnému sportu (tratě $3 \mathrm{~km}, 5 \mathrm{~km}$ a $10 \mathrm{~km}$ ).

Speciální olympiády jsou sportovním hnutím, které je určeno osobám s MP s diagnostikovaným IQ nižším než 75 nebo s vícečetnými vadami na bázi MP, a to ve věku od 8 let výše (pro národní soutěže a vyšší), pro trénink v programu „mladý sportovec“ již od 3 let.

Sportovní filosofie Speciálních olympiád je založena na principu relativity vzhledem $\mathrm{k}$ aktuálnímu výkonu, to znamená na kompozici finálových skupin dle limitů postižení, prezentovaných aktuálním spor- 
tovním výkonem mezi kvalifikací a finále. Je vyjádřený pravidlem tzv. maximálního úsilí, tj. soutěžení s plným nasazením v kvalifikaci i ve finále, přičemž rozdíl mezi výkonem $\mathrm{v}$ kvalifikaci a ve finále u trénovaných sportovců nemůže dosáhnout vyššího rozdílu než $20 \%$, resp. $15 \%$. Filosofie SO podtrhuje právo osob s MP všech limitů i věkových kategorií na účast v tréninku a sportovních soutěžích. Hlavním obsahem je celoroční sportovní trénink a sportovní soutěže v olympijských druzích sportu či v jejich modifikacích. Speciální olympiády byly zařazeny do sítě olympijských soutěží v roce 1988 podpisem smlouvy mezi zakladatelkou SO Eunice Kennedy-Shriverovou a předsedou mezinárodního olympijského výboru Antonio J. Samaranchem s povolením užívat název „Světové hry Speciálních olympiád“. Do tohoto data byl oficiální název „Mezinárodní hry Speciálních olympiád“. Vztah mezi Inas-FID a SOI byl vyjasněn v roce 2004 oboustranně podepsanou úmluvou o spolupráci. Pro české prostředí z toho vyplývá možnost registrovat jednotlivce či klub v jednom zvoleném směru nebo i v obou směrech, a to i klub se stejným jménem. Vnitřní nepsaná dohoda vymezuje nesměšování financí klubů registrovaných $\mathrm{v}$ obou směrech a nedublovat účast jednoho sportovce $v$ obou typech soutěží na světových či evropských soutěžích v jednom roce. Světové hry Speciálních olympiád (WWSOG - World Winter Special Olympic Games) se konají vždy v lichém roce rok před letními či zimními olympijskými hrami.

Tab. 1: Přehled konání zimnich her Speciálních olympiád

\begin{tabular}{|l|l|l|}
\hline Rok a místo & Charakteristika & Situace ČHSO \\
\hline $\begin{array}{l}1977 \quad \text { SteamboatSprings } \\
\text { USA, Cololrado }\end{array}$ & $\begin{array}{l}\text { soutěže mezi státy } \\
\text { USA }\end{array}$ & bez účasti \\
\hline $\begin{array}{l}\text { 1981 Smuggler'sNatch } \\
\text { and Stowe, USA, Vermont }\end{array}$ & $\begin{array}{l}\text { soutěže mezi státy } \\
\text { USA bez účasti }\end{array}$ & soutěže mezi státy \\
$\begin{array}{l}\text { 1985 Park City } \\
\text { USA, Utah }\end{array}$ & USA & bez účasti \\
\hline
\end{tabular}


Winter sports within Special Olympics

Zimní sporty ve Speciálních olympiádách

\begin{tabular}{|c|c|c|}
\hline $\begin{array}{l}1989 \text { Reno a LakeTahoe } \\
\text { USA }\end{array}$ & $\begin{array}{l}\text { Mezinárodní } \\
\text { mistrovství SO: } \\
\text { státy USA, Norsko, } \\
\text { Polsko }\end{array}$ & bez účasti \\
\hline $\begin{array}{l}1993 \text { Schladming } \\
\text { Rakousko }\end{array}$ & $\begin{array}{l}\text { první hry s názvem } \\
\text { WWSOG (světové } \\
\text { hry Speciálních } \\
\text { olympiád), } \\
\text { první hry mimo } \\
\text { USA, patronace } \\
\text { Arnolda } \\
\text { Schwarzenegera }\end{array}$ & $\begin{array}{l}\text { první účast na } \\
\text { zimních hrách, } \\
\text { silná výprava: } \\
\text { běžecké lyžování } \\
\text { a floorhokej } \\
\text { (klasický) }\end{array}$ \\
\hline $\begin{array}{l}1997 \text { Toronto/ } \\
\text { Collingwood } \\
\text { Kanada }\end{array}$ & $\begin{array}{l}\text { experiment se } \\
\text { sjednocenými } \\
\text { běžeckými } \\
\text { soutěžemi, sjezdové } \\
\text { soutěže ve středisku } \\
\text { Blue Mountain } \\
\text { In, vybudovaného } \\
\text { českými } \\
\text { a slovenskými } \\
\text { emigranty z } 20 . \\
\text { a } 30 . \text { let dvacátého } \\
\text { století }\end{array}$ & $\begin{array}{l}\text { běžecké } \\
\text { lyžování (včetně } \\
\text { sjednocené } \\
\text { soutěže na } 1 \\
\text { km), sjezdové } \\
\text { lyžování, } \\
\text { floorhokej } \\
\text { (klasický) }\end{array}$ \\
\hline $\begin{array}{l}2001 \text { Anchorage } \\
\text { USA, Aljaška }\end{array}$ & $\begin{array}{l}\text { první světová soutěž } \\
\text { uskutečněná na } \\
\text { Aljašce, } \\
\text { zařazení } \\
\text { snowboardingu } \\
\text { a snowshoeingu }\end{array}$ & $\begin{array}{l}\text { běžecké } \\
\text { a sjezdové } \\
\text { lyžování, } \\
\text { floorhokej } \\
\text { (sjednocený) }\end{array}$ \\
\hline
\end{tabular}




\begin{tabular}{|l|l|l|}
\hline $\begin{array}{l}\text { 2005 Nagano (Hakuba) } \\
\text { Japonsko }\end{array}$ & $\begin{array}{l}\text { užití zařízení } \\
\text { vybudovaných } \\
\text { pro předchozí } \\
\text { olympiádu } \\
\text { a paralympiádu }\end{array}$ & $\begin{array}{l}\text { běžecké } \\
\text { a sjezdové } \\
\text { lyžování, } \\
\text { floorhokej } \\
\text { (sjednocený) }\end{array}$ \\
\hline $\begin{array}{l}\text { 2009 Boisy a Sunny Valey } \\
\text { USA, Idaho }\end{array}$ & $\begin{array}{l}\text { náhrada za původněžecké } \\
\text { plánované Sarajevo } \\
\text { a sjezdové } \\
\text { lyžování, } \\
\text { snow-boarding, } \\
\text { floorhokej } \\
\text { (sjednocený) }\end{array}$ \\
\hline 2013 PyeongChang & $\begin{array}{l}\text { místo zvoleno } \\
\text { po testování } \\
\text { olympijských } \\
\text { a paralympijských } \\
\text { her 2018 }\end{array}$ & $\begin{array}{l}\text { kěžecké (také } \\
\text { kategorie FREE) } \\
\text { a sjezdové } \\
\text { lyžování, } \\
\text { snow-boarding, } \\
\text { floorhokej } \\
\text { (sjednocený) }\end{array}$ \\
\hline
\end{tabular}

České hry zimních Speciálních olympiád se konají pravidelně každoročně od roku 1991 v měsíci lednu v Krkonoších. Střediskem je přátelská lokalita Malá Úpa - Pomezní boudy.

V počáteční etapě rozvoje zimních sportů v ČHSO národnímu mistrovství předcházel několikadenní tréninkový kemp a $\mathrm{v}$ závěru týdne soutěže. V současné době zvýšený počet soutěžních disciplín i závodníků, dodržení pravidla o kvalifikaci a finále umožňují realizovat pouze mistrovskou sportovní soutěž. Mistrovství je př́istupno všem registrovaným klubům a sportovcům v ČHSO bez ohledu na limitní výkonnost. Typické je, dle doporučení pravidel SO, zařazování doplňkových programů (kulturních, vzdělávacích, výzkumných). 
Speciální olympiády umožňují modifikace sportů či jejich disciplín, takže spektrum zimních sportů, rozšiřované od roku 1977, v současné době sestává z 8 oficiálně vypisovaných zimních sportů na světových zimních hrách. Ne všechny jsou v programu ČHSO.

Tab. 2: Spektrum a charakteristika sportů SO

\begin{tabular}{|c|c|c|}
\hline Sport & Charakteristika & Situace v ČHSO \\
\hline Běžecké lyžování & Viz další část & viz další část \\
\hline Sjezdové lyžování & $\begin{array}{l}\text { Disciplíny odvozeny od } \\
\text { olympijských disciplín: } \\
\text { slalom, G-S, super G. } \\
\text { Tři úrovně: začátečníci, } \\
\text { střední a pokročilí } \\
\text { (hodnocení závodníků } \\
\text { experty v kvalifikaci). } \\
\text { Rozdíl je ve sklonu } \\
\text { a délce svahu, počtu } \\
\text { branek. Povinné jsou } \\
\text { helmy a užití pouze } \\
\text { sedačkových vleků. }\end{array}$ & $\begin{array}{l}\text { rozvíjeno od } \\
\text { konce } 90 . \text { let, } \\
\text { první účast v r. } \\
1997 \text {; }\end{array}$ \\
\hline Snow-boarding & $\begin{array}{l}\text { Princip jako u sjezdového } \\
\text { lyžování. }\end{array}$ & $\begin{array}{l}\text { rozvíjeno od r. } \\
\text { 2005, první účast } \\
\text { v r. 2005; }\end{array}$ \\
\hline Snow-shoeing & $\begin{array}{l}\text { Běh na sněžnicích: tratě } \\
\text { od } 100 \text { m do } 10 \mathrm{~km} \text {, } \\
\text { systém jako v běžeckém } \\
\text { lyžování. }\end{array}$ & tréninkově \\
\hline Krasobruslení & $\begin{array}{l}\text { Disciplíny: jednotlivci } \\
\text { muži - ženy, páry - } \\
\text { možné i jako sjednocené. }\end{array}$ & nerozvíjí se \\
\hline
\end{tabular}




\begin{tabular}{|c|c|c|}
\hline $\begin{array}{l}\text { Rychlobruslení na } \\
\text { krátké dráze }\end{array}$ & $\begin{array}{l}\text { Disciplíny: } 500 \mathrm{~m}, 1 \mathrm{~km} \text {, } \\
3 \mathrm{~km} .\end{array}$ & nerozvíjí se \\
\hline Floorhokej & $\begin{array}{l}\text { Sálový sport, odvozený } \\
\text { od hokeje (kroužek } \\
\text { a dřevěná tyč), možný } \\
\text { jako koedukovaný } \\
\text { a sjednocený. Do zimních } \\
\text { her zařazen proto, aby } \\
\text { byla umožněna účast } \\
\text { i sportovcům z "jižních } \\
\text { zemí" }\end{array}$ & $\begin{array}{l}\text { rozvíjen od } \\
\text { vstupu ČHSO do } \\
\text { mezinárodního } \\
\text { kontextu; }\end{array}$ \\
\hline Floorball & $\begin{array}{l}\text { Sálový sport, motivy } \\
\text { zařazení jako } \\
\text { u floorhokeje (plastová } \\
\text { hokejka a plastový } \\
\text { míček). Je méně } \\
\text { kontaktní. V současné } \\
\text { době jako ukázkový sport } \\
\text { se zařazením na hrách } \\
2017 \text {. }\end{array}$ & $\begin{array}{l}\text { rozvíjí se jako } \\
\text { sjednocený, počítá } \\
\text { se s účastí v r. } \\
2017 ;\end{array}$ \\
\hline Modifikace biatlonu & $\begin{array}{l}\text { Není v oficiálních } \\
\text { sportech SOI. }\end{array}$ & $\begin{array}{l}\text { kombinace běhu } \\
\text { na sněžnicích } \\
\text { a laserové střelby; } \\
\text { zařazováno pro } \\
\text { zpestření zimních } \\
\text { sportů, } \\
\text { z tréninkových } \\
\text { důvodů; }\end{array}$ \\
\hline
\end{tabular}




\section{Běžecké lyžování v rámci SO a ČHSO}

Běžecké lyžování v rámci SO a ČHSO se odvíjí od pravidel FISu. Modifikace, povolené pravidly SOI, se týkají úpravy tzv. „malých - A“ disciplín, „středních B1“ a „velkých - B“ disciplín. Model je analogický modelu ve sjezdovém lyžování (A - začátečníci [beginners, novices], B1 střední úroveň [intermediate], B - pokročilí [advancers]). Malé disciplíny jsou určeny také sportovcům s intenzivnějšími limity kognitivními i motorickými. Disciplíny mezi A, B1a B nelze kombinovat, přechodovou disciplínou je trat' $3 \mathrm{~km}$. Důvodem je, že neodpovídá pravidlu fair-play, aby schopnější sportovec se účastnil v malých disciplínách, mnohdy se v nich ani necítí. Opačně, více limitovaný sportovec nemůže velké disciplíny zvládnout, není to bezpečné, neposiluje to radost z účasti ve sportu. Obvyklé však je, že sportovci začínají v malých disciplínách a později přecházejí do vyšších. Tyto zkušenosti jsou i se sportovci s poruchou autistického spektra, kteří po 5 a více letech účasti v malých disciplínách zvládají samostatně a úspěšně tratě na $500 \mathrm{~m}$ a $1 \mathrm{~km}$.

\section{A: běh na 50 a $100 \mathrm{~m}$}

Trat' je upravena na rovině s 8 paralelními stopami, obdobně jako na atletické dráze. Soutěž má společný start, běh, resp. chůze je s holemi, trat' se musí zvládnout způsobem střídavým (prezentace rovnováhy, dovednosti s koordinací), nikoliv soupaž.

\section{B1: $500 \mathrm{~m}-1 \mathrm{~km}-3 \mathrm{~km}$}

Tratě odpovídají pravidlům FIS, tj. musí obsahovat kromě běhu po rovině také stoupání a sjezdy, zatáčení. U tratí na 500 a 1 km se neřeší technika, u tratě na $3 \mathrm{~km}$ se musí deklarovat užití technicky klasické nebo volné (s užitím bruslení).

B: $3 \mathrm{~km}-5 \mathrm{~km}-7,5 \mathrm{~km}-10 \mathrm{~km}$

Tratě odpovídají pravidlům FIS, tj. musí obsahovat kromě běhu po rovině také stoupání, sjezdy i zatáčení v obou směrech. Od 3 km výše se obvykle trat' řeší opakovanými koly nebo smyčkami, což už je náročné 
na kognici i orientaci závodníka. U všech tratí se musí deklarovat užití technicky klasické nebo volné (s užitím bruslení). Pořadatel má právo dle místních podmínek upravit délky tratí. To se stalo např. při WWSOG 2013 v PyeongChangu (trat' 2,5 km). Pořadatel má právo zvolit typ startu: hromadný či postupný po jednotlivcích či dvojicích. Na WWSOG se nejčastěji volí start po dvojicích, v ČHSO se stále více prosazuje start hromadný $\mathrm{z}$ důvodu tréninku pro starty štafet.

Štafety $4 \times 1 \mathrm{~km}$ se řeší opět dle pravidel FISu, tj. délka tratě, předávkové území, způsob předání štafety. Mohou se zúčastnit pouze ti, kterým byl změřen čas na $1 \mathrm{~km}, \mathrm{i}$ když v individuálním závodě běží např. trat' 3 km nebo vyšší. Je možné sestavit štafety koedukované. Start je zásadně hromadný, v následných vlnách. Např. WWSOG 2013 v PyeongChangu takto startovalo 32 štafetových týmů. Závodníci na jednotlivých úsecích jsou označeni barevnými čísly. Při soutěži mají trenéři právo př́ipravit rozhodčím daného závodníka k postavení do patřičné pozice pro předávku, nemají právo vstupu do předávkového území. Tréning pro štafety není jednoduchý, ovšem vlastní závod je vysoce emotivní, sportovci oblíbený a je evidentní pozorovat jejich týmovou snahu.

V tabulce 3 předkládáme pro ilustraci některé výsledky z národních her ČHSO v letech 2011 až 2013. Jsou patrné rozdíly, přičemž i ,slabé výsledky“ reprezentují maximální úsilí závodníka v rámci jeho limitů a možnost reprezentace na vyšších soutěžích než národních.

Tab. 3: Ilustrace výsledků v běžeckých soutěžich na národních hrách ČHSO a WWSOG

\begin{tabular}{|l|l|l|l|}
\hline Trat' & $\begin{array}{l}\text { Nejslabší } \\
\text { výsledek }\end{array}$ & $\begin{array}{l}\text { Obvyklý } \\
\text { výsledek }\end{array}$ & $\begin{array}{l}\text { Nejlepší } \\
\text { výsledek }\end{array}$ \\
\hline 50 m muži i ženy & $6-9 \mathrm{~min}$. & $30 \mathrm{sec}$. & kolem $10 \mathrm{sec}$ \\
\hline 100 m muži i ženy & $7-13 \mathrm{~min}$. & $1 \mathrm{~min}$. & kolem $30 \mathrm{sec}$. \\
\hline
\end{tabular}




\begin{tabular}{|l|l|l|l|}
\hline $\begin{array}{c}1 \mathrm{~km} \text { ženy } \\
\text { muži }\end{array}$ & $\begin{array}{l}17 \mathrm{~min} . \\
16 \mathrm{~min} .\end{array}$ & $\begin{array}{l}10-11 \mathrm{~min} . \\
9 \mathrm{~min} .\end{array}$ & $\begin{array}{l}8 \mathrm{~min} . \\
7 \mathrm{~min} .\end{array}$ \\
\hline $\begin{array}{c}3 \mathrm{~km} \text { ženy } \\
\text { muži }\end{array}$ & $\begin{array}{l}27: 30 \mathrm{~min} . \\
31: 20 \mathrm{~min} .\end{array}$ & $\begin{array}{l}16 \mathrm{~min} . \\
15 \mathrm{~min} .\end{array}$ & $\begin{array}{l}12 \mathrm{~min} . \\
9: 30 \mathrm{~min} .\end{array}$ \\
\hline $\begin{array}{c}5 \mathrm{~km} \text { ženy } \\
\text { muži }\end{array}$ & $\begin{array}{l}60 \mathrm{~min} . \\
55 \mathrm{~min} .\end{array}$ & $\begin{array}{l}37 \mathrm{~min} . \\
28 \mathrm{~min} .\end{array}$ \\
\hline $\begin{array}{l}\text { WWSOG, 2,5 km } \\
\text { žena ČHSO }\end{array}$ & & & $12: 49 \mathrm{~min}$. \\
\hline $\begin{array}{l}\text { WWSOG, 5 km } \\
\text { žena ČHSO }\end{array}$ & $\begin{array}{l}\text { první } \\
\text { z pětičlenné } \\
\text { finálové skupiny }\end{array}$ & & $32 \mathrm{~min}$. \\
\hline $\begin{array}{l}\text { WWSOG }- \text { ženy } \\
\text { první }\end{array}$ & $\begin{array}{l}\text { z šestičlenné } \\
\text { finálové skupiny }\end{array}$ & & $20: 25 \mathrm{~min}$. \\
\hline $\begin{array}{l}\text { WWSOG 2013 } \\
\times 1 \mathrm{~km}-\text { muži }\end{array}$ & & $22: 12 \mathrm{~min}$. \\
\hline
\end{tabular}

Trénink v běžeckém lyžování a sekundárně úspěšné Absolvování soutěží má další hlediska, tj. nácvik sociálního chování v kontextu běžeckého lyžování. Sportovec se ocitá v novém prostředí, kde je odlišný jazyk, jiné formy bydlení a stravování, profesionální podmínky sportovišt' a náročnost a kvalita tratí na rozdíl od domácích amatérských, řešení volného času. Samozřejmě trénink na náročnějších tratí, mazání lyží, atd., což už přesahuje rámec základních informací.

\section{ZÁVĚR}

Zimním sportům pro osoby s mentálním postižením není v literatuře odborné či metodické věnována dostatečná pozornost. Je třeba rozlišit systém zimních sportů a) v rámci Inas (ČSMPS) v normativním pojetí, kdy součástí soutěží je běžecké a sjezdové lyžování; b) v rám- 
ci SO (ČHSO), v relativním pojetí, kdy součástí je širší spektrum sportů s možnými modifikacemi disciplín. Mezinárodní hry SO se uskutečňují od roku 1977 s tím, že od roku 1993 jsou upraveny do pojetí světových zimních her SO (WWSOG). Zimní sporty vycházejí z pravidel FISu, přičemž modifikace jsou uskupeny dle principu „malých“ a „velkých disciplín $(A-B 1-B)$. Disciplíny, rozčleněné dle tohoto principu, nemůže sportovec SO kombinovat. Pro trénink a úspěšnou účast na vrcholových soutěžích je třeba trénovat (a zvládnout) i požadované vzorce sociálního chování. Pro užití v praxi doporučujeme zařadit tématiku zimních sportů osob s MP do vzdělávacích programů studujících v programech ,tělesná výchova a sport“, ale i do vzdělávacích licencí lyžařské federace v České republice. Ve vzdělávání trenérů ČHSO toto téma je součásti registrace klubu pro participaci ve sjezdovém či běžeckém lyžování.

\section{LITERATURA}

DePaw, K., \& Gavron, S. J. (2005). Disability sport (2 ${ }^{\text {nd }}$ edition). Champaign, IL: Human Kinetics, Inc.

Ješina, O. (2007). Aplikované pohybové aktivity v zimní přirodě. Olomouc: Univerzita Palackého.

Ješina, O., Janečka, Z. a kol. (2008). Aplikované pohybové aktivity v zimní prírodě II. Olomouc: Univerzita Palackého.

Ješina, O., Kudláček, M. a kol. (2011). Aplikovaná tělesná výchova. Olomouc: Univerzita Palackého.

Ješina, O., Hamřík, Z. a kol. (2011). Podpora aplikovaných pohybových aktivit v kontextu volného času. Olomouc: Univerzita Palackého.

Porretta, D. L. \& Sherrill, C. (2005). Research APAQ at Twenty: A Documentary Analysis. Adapted Physical Activity Quarterly 22 (2).

Shephard, R. J. (1990). Fitness of Special Population. Champaign, IL: HumanKinetics, Inc.

Sherril, C. (2003). Adaptedphysicalactivity, recreation and sport: crossdisciplinary and lifespan ( $6^{\text {th }}$ edition). New York, NY: McGraw-Hill.

Tilinger, P., \& Lejčarová, A. a kol. (2012). Sport osob s intelektovým postižením. Praha: Univerzita Karlova, Karolinum. 
Válková, H. (2012). Sporty osob s MP. In Z. Janečka a kol. (Ed.) Vybrané kapitoly ze sportu osob se zdravotním postižením. Olomouc: Univerzita Palackého.

Válková, H. (2012). Teorie aplikovaných pohybových aktivit pro užití $v$ praxi 1. Olomouc: Univerzita Palackého.

Válková, H. (2013). Sumarizace osobních zkušeností na všech WWSOG a národních hrách v ČR.

Winnick, J. P. (1990). Adaptedphysicaleducation and sport. Champaign, IL: HumanKinetics, Inc.

\section{INTERNETOVÉ ODKAZY:}

www.inas.org/technical/eligibility-and-classification

www.specialolympics.cz

www.specialolympics.org

\section{KONTAKT:}

prof. PhDr. Hana Válková, CSc., Hana.valkova@upol.cz 